\title{
The Effect of Insulin on Pyruvate Dehydrogenase Interconversion in Heart Muscle of Alloxan-Diabetic Rats
}

\author{
J. Ohlen, E. A. Siess, G. Löffler, and O.H. Wieland \\ Forschergruppe Diabetes and Klinisch-chemisches Institut, Städtisches Krankenhaus München-Schwabing, München, FRG
}

\begin{abstract}
Summary. Evidence is presented for regulation by insulin of pyruvate dehydrogenase (PDH) interconversion in rat heart muscle in vivo and in vitro. In the alloxan diabetic rat the active (dephospho) enzyme amounted only to $12 \%$ of total PDH and was restored to $42 \%$ by insulin. Antilipolytic treatment of the diabetic animals was ineffective, indicating that the action of insulin was independent of a lowering of plasma non-esterified fatty acid concentration. On perfusion of isolated hearts from diabetic rats in the presence of glucose the proportion of pyruvate dehydrogenase in the active form remained low but was fully restored upon addition of insulin $(2 \mathrm{mU} / \mathrm{ml})$ to the medium. No effect of insulin was obtained in the absence of glucose. The correlation between the rate of pyruvate decarboxylation in the perfused heart and of pyruvate dehydrogenase activity, in vitro, suggests that in the diabetic heart the entry of pyruvate into the citric acid cycle is largely controlled by covalent modification of the pyruvate dehydrogenase complex rather than by feedback inhibition. The possible role of insulin therein is discussed.
\end{abstract}

Key words: Insulin, pyruvate dehydrogenase, enzyme interconversion, heart muscle, alloxan-diabetes, heart perfusion.

Inhibition of pyruvate oxidation is a well known alteration of heart muscle metabolism in diabetes and starvation [1]. The responsible enzyme, the pyruvate dehydrogenase (PDH, EC 1.2.4.1) complex is regulated by either feedback control by acetyl-CoA and NADH $[1,2]$ or by enzymatic phosphorylation and dephosphorylation reactions leading to the inactive form $\left(\mathrm{PDH}_{\mathrm{b}}\right)$ or the active form $\left(\mathrm{PDH}_{\mathrm{a}}\right)$, respectively $[3,4]$. Previous work from this laboratory had shown that in heart muscle of normal fed rats about two-thirds of total PDH activity was found as $\mathrm{PDH}_{\mathrm{a}}$ whereas only about one tenth of total activity was found as $\mathrm{PDH}_{\mathrm{a}}$ in starved or ketoacidotic alloxan diabetic animals. Furthermore, $\mathrm{PDH}_{\mathrm{a}}$ levels lowered by diabetes and by fasting could be normalized by insulin treatment and by refeeding of carbohydrate, or treatment with nicotinic acid, respectively [5]. From these and other experiments $[6,7]$ it was suggested that the release and oxidation of free fatty acids (FFA) might be an important factor for the regulation of PDH. The aim of the present work was to study the possible role of insulin in PDH interconversion in the diabetic heart muscle, in vivo and in vitro. Furthermore, tracer experiments were carried out in order to compare the rate of pyruvate oxidation in the perfused heart with the activity of $\mathrm{PDH}$ measured after extraction of the heart muscle. Preliminary reports have appeared elsewhere $[8,9]$.

\section{Materials and Methods}

\section{Materials}

Enzymes and coenzymes were products of Boehringer, Mannheim (Gcrmany). 2-Deoxyglucose was from EGA-Chemie, Steinheim (Germany). Glucagon-free bovine insulin $(27 \mathrm{U} / \mathrm{mg}$ ) came from Hoechst, Frankfurt (Germany). Alloxan and all other reagents were analytical grade products from E. Merck, Darmstadt (Germany).

\section{Animals}

Male Sprague-Dawley rats (W. Gassner, Sulzfeld, Germany) weighing $125-150 \mathrm{~g}$ and $170-220 \mathrm{~g}$ 
were used for the in vitro and the in vivo experiments, respectively. Unless stated otherwise the animals had free access to water and a standard laboratory diet (Labortierfutter $57 \mathrm{Z}$, J. Zahn II, Hockenheim, Germany).

\section{Induction of Diabetes}

Alloxan-diabetes was induced by injection of $80-100 \mathrm{mg} / \mathrm{kg}$ body weight of alloxan into a tail vein of starved $(16-30 \mathrm{~h})$ rats. For one week the animals received 1.5-4 $\mathrm{U}$ of bovine depot insulin SC every $12 \mathrm{~h}$, which was sufficient to prevent gross urinary sugar excretion, assessed with Dextrostix (Ames Co., Miles Laboratories, Frankfurt/M., Germany).

Prior to use insulin was withdrawn for at least $36 \mathrm{~h}$ and the rats showing plasma concentrations of glucose, ketone bodies and FFA higher than $22 \mathrm{mmol} / \mathrm{l}, 1.5 \mathrm{mmol} / \mathrm{l}$ and $0.8 \mathrm{mmol} / 1$ were used. Mean \pm SEM of these measurements were 35.5 $\pm 1.2 \mathrm{mmol} / \mathrm{l}, 7.1 \pm 0.6 \mathrm{mmol} / 1$ and $2.0 \pm 0.1 \mathrm{mmol} / 1$, respectively.

\section{Heart Perfusion}

Hearts were prepared under Nembutal anaesthesia $(5 \mathrm{mg} / \mathrm{kg}$ body weight IP) according to the Langendorff procedure [10], modified by Morgan et al. [11]. After 1-1.5 min of preperfusion in an open system with $8 \mathrm{ml}$ of substrate-free Krebs-Henseleit bicarbonate buffer [12], saturated with $\mathrm{O}_{2}$ and $\mathrm{CO}_{2}$ $(95: 5)$, hearts were perfused for $30 \mathrm{~min}$ in a recirculating system with $17 \mathrm{ml}$ of Krebs-Henseleit bicarbonate buffer, $\mathrm{pH} 7.4$, containing $20 \mathrm{~g} / 1$ bovine serum albumin (Serva, Heidelberg, Germany) (= basal medium) at a constant pressure of $60 \mathrm{mmHg}$. Before use, the perfusion medium was filtered through a Millipore filter, type SSWP. The flow rate $(12-14 \mathrm{ml} / \mathrm{min})$ and frequency of heart contractions (220-260/min) remained constant during the perfusion period.

\section{Determination of Pyruvate Decarboxylation} by the Perfused Heart Muscle

Pyruvate decarboxylation was determined using $3,4-{ }^{14} \mathrm{C}$-labelled glucose (New England Nuclear, Dreieichenhain, Germany), which yields pyruvate and lactate labelled in the carboxyl position. In each experiment 1-2 $\mu \mathrm{Ci}$ of labelled glucose $(13.5 \mathrm{Ci} /$ mole) were added to the basal medium containing $10 \mathrm{mmol} / 1$ glucose.

For radioactivity measurements $0.5 \mathrm{ml}$ of medium was deproteinized with $0.5 \mathrm{ml}$ of $6 \%$
$\mathrm{HClO}_{4}$, neutralized with solid $\mathrm{KHCO}_{3}$, and separated on a Dowex $1 \times 8$ column $(0.6 \times 8 \mathrm{~cm}$, formate form, 200-400 mesh) at $4^{\circ} \mathrm{C}$. On elution at $0.3 \mathrm{ml} / \mathrm{min}$ glucose was recovered in the first peak with $15 \mathrm{ml} \mathrm{H}_{2} \mathrm{O}$ (3 fractions of $5 \mathrm{ml}$ each), whereas lactate and pyruvate appeared separately on elution with $25 \mathrm{ml}$ of $0.3 \mathrm{~mol} / 1 \mathrm{HCOOH}$ (5 fractions), and $25 \mathrm{ml}$ of $6 \mathrm{~mol} / 1 \mathrm{HCOOH}$ ( 5 fractions), respectively. The radioactivity of $2 \mathrm{ml}$ of the combined fractions mixed with $12 \mathrm{ml}$ of Bray's solution [13] was determined in a Mark II liquid scintillation counter and corrected for quenching by internal standard. $98.4-102.3 \%$ of the radioactivity placed on the column was recovered in the combined eluates. The specific radioactivity of glucose remained constant during a period of $30 \mathrm{~min}$ of perfusion. The specific labelling of lactate and pyruvate was half that of glucose, indicating equilibration of the $\mathrm{C}_{3}$-pool.

The position of ${ }^{14} \mathrm{C}$ in lactate and pyruvate was examined after permanganate oxidation according to Katz et al. [14]. Ninety-two percent of the label incorporated into lactate and pyruvate could be detected in the carboxyl position after $30 \mathrm{~min}$ of heart perfusion with $3,4-{ }^{14} \mathrm{C}$-glucose.

\section{Measurement of ${ }^{14} \mathrm{CO}_{2}$}

${ }^{14} \mathrm{CO}_{2}$ was trapped in a vessel fitted to the gas outlet of the perfusion chamber containing $10 \mathrm{ml}$ of $25 \%$ $(\mathrm{v} / \mathrm{v})$ ethanolamine in methanol. ${ }^{14} \mathrm{CO}_{2}$ present as bicarbonate in the medium was collected at the end of the perfusion according to Gliemann [15].

The sum of the radioactivities recovered in glucose, lactate, pyruvate, $\mathrm{CO}_{2}$ (medium plus gas phase), and in the heart tissue after perfusion amounted to $94-98 \%$ of the radioactivity added.

\section{Preparation of Tissue Extracts and Pyruvate Dehydrogenase Determinations}

The hearts were removed from anaesthetised rats or from the perfusion chamber with a Wollenberger clamp precooled in liquid $\mathrm{N}_{2}$, and the frozen tissue was pulverized in a mortar. Homogenization was performed by treating $0.2 \mathrm{~g}$ of pulverized heart tissue in $2.6 \mathrm{ml} \mathrm{K}{ }^{+}$phosphate buffer $(20 \mathrm{mmol} / 1$ in $4.3 \mathrm{~mol} / 1$ glycerol, $\mathrm{pH} 7.0)$ at $-10^{\circ} \mathrm{C}$ twice $(60 \mathrm{sec}$ each with an intermission of $60 \mathrm{sec}$ ) with a high speed tissue disintegrator (Ultra Turrax TP $10 \mathrm{~N}$, Jahnke und Kunkel, Stauffen i. Breisgau, Germany). The temperature did not rise above $-4^{\circ} \mathrm{C}$ during homogenization. PDH activities were measured before and after activation with $\mathrm{Mg}^{2+}$ by the dismutation assay described earlier [5].

One unit of PDH activity corresponds to the formation of $1 \mu \mathrm{mol}$ acetylphosphate per min at $37^{\circ} \mathrm{C}$. 
Table 1. Effect of insulin on glucose metabolism and on pyruvate dehydrogenase of the perfused diabetic rat heart. For experimental details see Methods

\begin{tabular}{|c|c|c|c|c|c|c|c|c|}
\hline Group & $\mathrm{n}$ & Additions & \multicolumn{3}{|c|}{$\begin{array}{l}\text { Metabolite changes } \\
\left(\mu \text { moles } \times \text { g wet wt. }{ }^{-1} \times 30 \mathrm{~min}^{-1}\right)\end{array}$} & $\begin{array}{l}{ }^{14} \mathrm{CO}_{2} \\
\text { Production } \\
\mu \text { moles } \times \mathrm{g} \text { wet } \\
\text { wt. }^{-1} \times \text { min }^{-1}\end{array}$ & $\begin{array}{l}\mathrm{PDH}_{\mathrm{a}} \\
\text { Units } \times \mathrm{g} \\
\text { wet wt. }\end{array}$ & $\begin{array}{l}\% \text { of } \\
\mathrm{PDH}_{\mathrm{a}+\mathrm{b}}\end{array}$ \\
\hline A (control) & 22 & glucose, $10 \mathrm{mmol} / 1$ & $-95.7 \pm 4.8$ & $+26.2 \pm 2.8$ & $+5.7 \pm 0.4$ & $1.33 \pm 0.05$ & $1.83 \pm 0.10$ & 58 \\
\hline $\mathrm{B}$ (diabetic) & 11 & glucose, $10 \mathrm{mmol} / \mathrm{l}$ & $-47.7 \pm 6.2$ & $+18.0 \pm 2.3$ & $+4.8 \pm 1.6$ & $0.45 \pm 0.04$ & $0.38 \pm 0.02$ & 13 \\
\hline \multirow{2}{*}{ C (diabetic) } & 20 & glucose, $10 \mathrm{mmol} / 1$ & & & & & & \\
\hline & & insulin, $2 \mathrm{mU} / \mathrm{ml}$ & $-93.9 \pm 6.1$ & $+50.5 \pm 3.8$ & $+5.0 \pm 0.5$ & $0.77 \pm 0.04$ & $1.69 \pm 0.11$ & 54 \\
\hline D (diabetic) & 10 & insulin, $2 \mathrm{mU} / \mathrm{ml}$ & $+1.8 \pm 0.2$ & $+18.9 \pm 1.2$ & $+1.4 \pm 0.3$ & - & $0.50 \pm 0.06$ & 15 \\
\hline \multirow[t]{2}{*}{$\mathrm{E}$ (diabetic) } & 19 & deoxyglucose, $10 \mathrm{mmol} / \mathrm{l}$ & & & & & & \\
\hline & & insulin, $2 \mathrm{mU} / \mathrm{ml}$ & $+1.5 \pm 0.3$ & $+10.3 \pm 1.0$ & $+0.8 \pm 0.1$ & - & $2.83 \pm 0.20$ & 74 \\
\hline
\end{tabular}

\section{Analytical Methods}

Glucose, lactate, pyruvate, acetoacetate and 3-hydroxybutyrate were determined in deproteinized and neutralized perfusate or plasma samples by standard enzymatic procedures [16]. Protein was measured by a modified Biuret procedure [17]. Free fatty acid determinations in plasma samples were carried out by a modified [18] Duncombe procedure [19].

\section{Statistical Evaluation}

Results are presented as the mean $(\overline{\mathrm{x}}) \pm$ SEM. Since a normal distribution of the various parameters was not predictable statistical significance was assessed with the Wilcoxon-Mann-Whitney rank test [20].

\section{Results}

\section{Effect of Insulin on the Phosphorylation State of $P D H$ in vivo}

In the heart muscle from diabetic rats two hours after the injection of $250 \mathrm{mg} / \mathrm{kg}$ nicotinic acid SC, $11.8 \%$ of total PDH activity $(\mathrm{n}=16)$ was present in the active dephospho form $\left(=\mathrm{PDH}_{\mathrm{a}}\right)$, when the concentration of plasma FFA was $0.29 \pm 0.03$ mequ/l $(\mathrm{n}=12)$. Rats kept on insulin until death responded to the same antilipolytic treatment with an increase of $\mathrm{PDH}_{\mathrm{a}}$ to $41.6 \%(\mathrm{n}=13)$, plasma FFA being $0.22 \pm 0.01 \mathrm{mequ} / \mathrm{l}(\mathrm{n}=11)$. Total PDH activities were determined to be 6.8 $\pm 0.4 \mathrm{U} / \mathrm{g}$ wet wt. $(\mathrm{n}=16)$ and $8.9 \pm 0.4 \mathrm{U} / \mathrm{g}$ wet wt. $(n=13)$ in the diabetic and insulin treated groups, respectively. In the kidney of the diabetic animals $\mathrm{PDH}_{\mathrm{a}}$ activity was four times higher than in heart muscle and was not elevated by insulin. Fur- ther, there was no change of total PDH activity in kidney $(5 \pm 0.2 \mathrm{U} / \mathrm{g}$ wet wt., $(\mathrm{n}=16)$ and 4.5 $\pm 0.2 \mathrm{U} / \mathrm{g}$ wet wt. $(\mathrm{n}=12)$ in the diabetic and the insulin treated group, respectively).

\section{Effect of Insulin on the Phosphorylation State of $P D H$ in vitro}

The hearts from diabetic rats perfused for $30 \mathrm{~min}$ with glucose had a much lower level of $\mathrm{PDH}_{\mathrm{a}}$ than the hearts from normal animals (Table 1), but the same total PDH activity $(3.10 \pm 0.15 \mathrm{U} / \mathrm{g}$ wet wt., $\mathrm{n}=8$ ). As further shown in Table 1 insulin added to the incubation medium restored the $\mathrm{PDH}_{\mathrm{a}}$ value of the normal control in the diabetic hearts and this effect was dependent on the presence of glucose or deoxyglucose.

The decrease with insulin deficiency in the active PDH form was accompanied by a marked fall of the ${ }^{14} \mathrm{CO}_{2}$ output (Table 1) and by a diminution of glucose uptake and lactate production, by $50 \%$ and $31 \%$, respectively. In agreement with an earlier report [33] insulin added to the perfusion medium normalized glucose uptake, markedly increased lactate formation but did not yield the normal rate of ${ }^{14} \mathrm{CO}_{2}$ production (Table 1). Regarding the relationship between pyruvate decarboxylation and $\mathrm{PDH}_{a}$ activity extractable from heart muscle, the present study took advantage of the fact that ${ }^{14} \mathrm{C}$-glucose labelled in the $\mathrm{C}_{3}$ and $\mathrm{C}_{4}$ positions yields almost exclusively carboxyl- ${ }^{14}$-C-pyruvate and lactate. As no isotope dilution of the $\mathrm{C}_{3}$-pool was measurable during the $30 \mathrm{~min}$ perfusion period and ${ }^{14} \mathrm{CO}_{2}$ redistribution, in view of the low pyruvate carboxylase activity in heart muscle [37], appears to be negligible, it seemed reasonable to estimate the flux of pyruvate through the $\mathrm{PDH}$ step from the ${ }^{14} \mathrm{CO}_{2}$ formed on the basis of one mole of $3,4-{ }^{14} \mathrm{C}$-glucose yielding two moles of $1-{ }^{14} \mathrm{C}$-pyruvate. 
According to Table $1{ }^{14} \mathrm{CO}_{2}$ production by hearts from normal and diabetic rats corresponded to $75 \%$ and $100 \%$ respectively, of $\mathrm{PDH}_{\mathrm{a}}$ activity. In the presence of insulin (group C), however, the rate of ${ }^{14} \mathrm{CO}_{2}$ formation apparently accounted only for $45 \%$ of the $\mathrm{PDH}_{\mathrm{a}}$ activity.

\section{Discussion}

In an earlier study an inverse relationship between the levels of plasma FFA and $\mathrm{PDH}_{\mathrm{a}}$ in heart muscle and kidney from intact rats was demonstrated [5]. In starved rats, for example, $\mathrm{PDH}_{\mathrm{a}}$ of heart muscle rose from $7 \%$ to $65 \%$ and that of kidney from $15 \%$ to $78 \%$ when the concentration of plasma FFA was normalized by nicotinic acid treatment [5]. In the present study on diabetic rats the amount of heart muscle $\mathrm{PDH}_{\mathrm{a}}$ was much lower than expected [5] from the plasma FFA concentrations after nicotinic acid treatment, while that of the kidney approached the normal value. As diabetic animals injected with insulin showed a marked increase of $\mathrm{PDH}_{\mathrm{a}}$ in heart muscle but not in kidney it is reasonable to conclude that insulin is involved in the regulation of PDH interconversion solely in the former organ. This view is further substantiated by our studies conducted on the perfused heart. These experiments clearly showed that insulin added in vitro was capable of restoring the level of $\mathrm{PDH}_{\mathrm{a}}$ of diabetic hearts to normal values (Table 1). This result and the values for $\mathrm{PDH}_{\mathrm{a}}$ in diabetic and normal heart muscle differ from those reported by Kerbey et al. [21], who found only $25-30 \%$ and $1.5 \%$ of total enzyme activity present in the active form in perfused hearts from normal and diabetic rats. Moreover, insulin failed to restore normal $\mathrm{PDH}_{\mathrm{a}}$ levels in their preparations from diabetic rats. The reason(s) for thesc discrepancies are not clear; however, the experimental conditions with respect to age and strain of the animals, perfusion time and medium glucose concentration were different. Further, our animals had been kept on insulin for one week after alloxan injection and only those displaying severe ketoacidosis and hyperglycaemia after insulin withdrawal were used.

As to the mechanism of insulin action on PDH interconversion the hormone seems to act via PDH kinase rather than via PDH-phosphatase, since the activity of the latter enzyme proved to be normal in diabetes [36].

From the fact that insulin in heart muscle, like in adipose tissue [24], affects $\mathrm{PDH}_{\mathrm{a}}$ only in the presence of glucose or deoxyglucose, it appears that its effect, at least in part, could be explained by a lowering of the mitochondrial ATP/ADP ratio which may itself result from the increased consumption of cytosolic ATP for sugar phosphorylation and/or anabolic processes, in particular glycogen synthesis [33]. However, a number of additional factors, such as pyruvate concentration, the ratios of NADH/ NAD and of acetyl-CoA/CoA, have been demonstrated in studies with isolated rat heart mitochondria to act on PDH interconversion [21, 27-30]. Pertaining to pyruvate, insulin neither causes an accumulation in the perfusion medium (Table 1) nor in the heart tissue $[31,32]$. Also with respect to ATP and ADP insulin did not change the total cellular contents of perfused hearts from normal and diabetic animals $[34,35]$. These findings, however, do not exclude the possibility that opposite metabolite changes may occur in the mitochondrial and cytosolic spaces. That this can happen under special conditions has been demonstrated recently with isolated rat liver cells [38]. Unfortunately, no method is available at present to study the subcellular distribution of metabolites in heart cells.

As to the question of feedback control being operative on PDH in heart muscle the data presented in groups $\mathrm{A}$ and $\mathrm{B}$ of Table 1 are compatible with the view that the enzyme is not subject to great restraint in the intact cell. The discrepancy apparent in group $\mathrm{C}$ could, at least in part, be explained by the fact that the PDH activity prevailing at the end of the perfusion time has been compared with a rate of ${ }^{14} \mathrm{CO}_{2}$ formation averaged over the $30 \mathrm{~min}$ period. As insulin markedly increased $\mathrm{PDH}_{\mathrm{a}}$ activity during perfusion, the average enzyme activity must have been lower than that given in Table 1, group C. Thus it appears that in the isolated perfused heart muscle feedback control of PDH is less pronounced than in isolated heart mitochondria from normal fed rats since, during state 3 respiration, the rate of pyruvate decarboxylation accounts only for about $50 \%$ of $\mathrm{PDH}_{\mathrm{a}}$ activity [30].

Acknowledgement. The skilful technical assistance of Miss G. Stejskal is gratefully acknowledged. This work was supported by the Deutsche Forschungsgemeinschaft, Bad Godesberg, FRG.

\section{References}

1. Randle, P. J., Garland, P. B., Hales, C. N., Newsholme, E. A., Denton, R.M., Pogson, C. I.: Interactions of metabolism and the physiological role of insulin. Recent Prog. Horm. Res. 22, 1-48 (1966)

2. Wieland, O.H., v.Jagow-Westermann, B., Stukowski, B.: Kinetic and regulatory properties of heart muscle pyruvate dehydrogenase. Hoppe Seylers Z. Physiol. Chem. 350, 329-334 (1969)

3. Linn, T.C., Pettit, F.H., Reed, L.J.: $\alpha$-Keto acid dehydrogenase complexes. X. Regulation of the activity of the pyruvate dehydrogenase complex from beef kidney mitochondria by phosphorylation and dephosphorylation. Proc. Natl. Acad. Sci. USA 62, 234-241 (1969)

4. Wieland, O.H., v.Jagow-Westermann, B.: ATP-dependent inactivation of heart muscle pyruvate dehydrogenase and reactivation by $\mathrm{Mg}^{++}$. FEBS Lett. 3, 271-274 (1969) 
5. Wieland, O. H., Siess, E., Schulze-Wethmar, F.H., v. Funcke, H.J., Winton, B.: Active and inactive forms of pyruvate dehydrogenase in rat heart and kidney: effect of diabetes, fasting, and refeeding on pyruvate dehydrogenase interconversion. Arch. Biochem. Biophys. 143, 593-601 (1971)

6. Wieland, O.H., v. Funcke, H.J., Löffler, G.: Interconversion of pyruvate dehydrogenase in rat heart muscle upon perfusion with fatty acids or ketone bodies. FEBS Lett. 15, 295-298 (1971)

7. Whitehouse, S., Cooper, R.H., Randle, P.J.: Mechanism of activation of pyruvate dehydrogenase by dichloroacetate and other halogenated carboxylic acids. Biochem. J. 141, 761-774 (1974)

8. Siess, E. A., Wieland, O. H.: Wirkung von Insulin auf die Interkonvertierung der Pyruvatdehydrogenase im Rattenherzen, Abst.-Nr. 20. 8. Kongr. der Dtsch. Diabetes Ges. München 1973

9. Ohlen, J., Löffler, G., Wieland, O.H.: Zur Beeinflussung der Pyruvat-Dehydrogenase-Interkonvertierung des Herzmuskels durch Insulin. Hoppe Seylers Z. Physiol. Chem. (Abstr.) 354, 1226 (1973)

10. Langendorff, $O$.: Untersuchungen am überlebenden Säugetierherzen. Pfluegers Arch. 61, 291-332 (1895)

11. Morgan, H. E., Henderson, M. J., Regen, D. M., Park, C. R.: Regulation of glucose uptake in muscle. I. The effects of insulin and anoxia on glucose transport and phosphorylation in the isolated, perfused heart of normal rats. J. Biol. Chem. 236, 253-261 (1961)

12. Krebs, H. A., Henseleit, K.: Untersuchungen über die Harnstoffbildung im Tierkörper. Hoppe Seylers Z. Physiol. Chem. 210, 33-66 (1932)

13. Bray, G. A.: A simple efficient liquid scintillator for counting aqueous solutions in a liquid scintillation counter. Anal. Biochem. 1, 279-285 (1960)

14. Katz, J., Abraham, S., Chaikoff, I. L.: Analytical procedures using a combined combustion-diffusion vessel. An improved method for the degradation of carbon-14-labeled lactate and acetate. Anal. Chem. 27, 155-156 (1955)

15. Gliemann, J.: Insulin-like activity of dilute human serum assayed by an isolated adipose cell method. Diabetes 14, 643-649 (1965)

16. Bergmeyer, H.U.: Methoden der enzymatischen Analyse, 2nd edition, Vol. II. Weinheim/Bergstraße: Verlag Chemie 1970

17. Weiss, L.: Regulation der Lipidsynthese im Fettgewebe durch Insulin auf der Stufe der Pyruvatdehydrogenase. Habil. Schrift (Fachbereich Medizin), Universität München 1976

18. Guder, W., Weiss, L., Wieland, O.H.: Triglyceride breakdown in rat liver. The demonstration of three different lipasses. Biochim. Biophys. Acta 187, 173-185 (1969)

19. Duncombe, W.G.: The colorimetric micro-determination of long-chain fatty acids. Biochem. J. 88, 7-10 (1963)

20. Sachs, L.: Statistische Auswertungsmethoden. 3rd edition, p. 230. Berlin, Heidelberg, New York: Springer 1972

21. Kerbey, A.C., Randle, P.J., Cooper, R.H., Whitehouse, S., Pask, H.T., Denton, R. M.: Regulation of pyruvate dehydrogenase in rat heart. Mechanism of regulation of proportions of dephosphorylated and phosphorylated enzyme by oxidation of fatty acids and ketone bodies and of effects of diabetes: role of coenzyme $A$, acetyl-coenzyme $A$ and reduced and oxidized nicotinamide-adenine dinucleotide. Biochem. J. 154, 327-348 (1976)

22. Park, C. R., Morgan, H.E., Henderson, M.J., Regen, D. M., Cadenas, E., Post, R. L.: The regulation of glucose uptake in muscle as studied in the perfused rat heart. Recent Prog. Horm. Res. 17, 493-538 (1961)
23. Randle, P. J., Newsholme, E. A., Garland, P. B.: Regulation of glucose uptake by muscle. 8 . Effects of fatty acids, ketone bodies and pyruvate, and of alloxan-diabetes and starvation, on the uptake and metabolic fate of glucose in rat heart and diaphragm muscle. Biochem. J. 93, 652-665 (1964)

24. Weiss, L., Löffler, G., Wieland, O.H.: Regulation by insulin of adipose tissue pyruvate dehydrogenase. A mechanism controlling fatty acid synthesis from carbohydrates. HoppeSeylers Z. Physiol. Chem. 355, 363-377 (1974)

25. Denton, R.M., Randle, P.J.: Concentrations of glycerides and phospholipids in rat heart and gastrocnemius muscles. Effects of alloxan-diabetes and perfusion. Biochem. J. 104, 416-422 (1967)

26. Murthy, V.K., Shipp, J.C.: Accumulation of myocardial triglycerides in ketotic diabetes. Diabetes 26, 222-229 (1977)

27. Hansford, R. G.: Studies on the effects of coenzyme A-SH: acetyl coenzyme $A$, nicotinamide adenine dinucleotide: reduced nicotinamide adenine dinucleotide, and adenosine diphosphate: adenosine triphosphate ratios on the interconversion of active and inactive pyruvate dehydrogenase in isolated rat heart mitochondria. J. Biol. Chem. 251, 5483-5489 (1976)

28. Hansford, R. G.: Studies on inactivation of pyruvate dehydrogenase by palmitoylcarnitine oxidation in isolated rat heart mitochondria. J. Biol. Chem. 252, 1552-1560 (1977)

29. Portenhauser, R.: Interconversion of pyruvate dehydrogenase in mitochondria from rat heart, p. 42. Abstr. Commun. 9th Meet. Fed. Europ. Biochem. Soc. 1974

30. Portenhauser, R., Wieland, O.H.: Regulation of pyruvate dehydrogenase in heart mitochondria. Hoppe Seylers $Z$. Physiol. Chem. 358, 647-658 (1977)

31. Mowbray, J., Ottaway, J.H.: The flux of pyruvate in perfused rat heart. Eur. J. Biochem. 36, 362-368 (1973)

32. Mowbray, J., Ottaway, J. H.: The effect of insulin and growth hormone on the flux of tracer from labelled lactate in perfused rat heart. Eur. J. Biochem. 36, 369-379 (1973)

33. Chain, E. B., Mansford, K. R. L., Opie, L. H.: Effects of insulin on the pattern of glucose metabolism in the perfused working and Langendorff heart of normal and insulin-deficient rats. Biochem. J. 115, 537-546 (1969)

34. Randle, P. J.: Apparent reversal of insulin resistance in cardiac muscle in alloxan diabetes by 2 -Borneo stearate. Nature 221, 777 (1969)

35. Opie, L.H., Mansford, K.L.R., Owen, P.: Effects of increased heart work on glycolysis and adenine nucleotides in the perfused heart of normal and diabetic rats. Biochem. J. 124, 475-490 (1971)

36. Siess, E. A., Wieland, O. H.: Cellular distribution of pyruvate dehydrogenase phosphatase. Activity in normal, hyperinsulinized and diabetic rats. FEBS Lett. 65, 163-168 (1976)

37. Böttger, I., Wieland, O.H., Brdiczka, D., Pette, D.: Intracellular localization of pyruvate carboxylase and phosphoenolpyruvate carboxykinase in rat liver. Eur. J. Biochem. 8, 113-119 (1969)

38. Siess, E. A., Brocks, D. G., Lattke, H. K., Wieland, O. H.: Effect of glucagon on metabolite compartmentation in isolated rat liver cells during gluconeogenesis from lactate. Biochem. J. 166, 225-235 (1977)

Received: June 8, 1977,

and in revised form: September 19, 1977

Prof. Dr. O. H. Wieland

Forschergruppe Diabetes

Kölner Platz 1

D-8000 München 40

Federal Republic of Germany 